\title{
Celiac disease prevalence is not increased in patients with functional dyspepsia
}

\author{
Juan LASA, Liliana SPALLONE, Silvina GANDARA, Elsa CHAAR, \\ Saul BERMAN and David ZAGALSKY*
}

Received 4/7/2016 Accepted 6/9/2016

\begin{abstract}
Background - Previous evidence trying to assess the risk of celiac disease among dyspeptic patients has been inconclusive, showing in some cases notorious discrepancies. Objective - To determine the prevalence of celiac disease in patients with dyspepsia compared to healthy controls without dyspepsia. Methods - Adult patients under evaluation for dyspepsia were invited to participate. These patients were offered an upper gastrointestinal endoscopy with duodenal biopsies. On the other hand, asymptomatic adult volunteers who performed a preventive visit to their primary care physician were invited to participate and agreed to undertake an upper gastrointestinal endoscopy with duodenal biopsies as well. Those patients with histologic signs of villous atrophy were furtherly evaluated and serological tests were performed in order to determine celiac disease diagnosis. Celiac disease prevalence was compared between groups. Results - Overall, 320 patients with dyspepsia and 320 healthy controls were recruited. There were no significant differences in terms of gender or age between groups. Celiac disease diagnosis was made in $1.25 \%(4 / 320)$ of patients in the dyspepsia group versus $0.62 \%(2 / 320)$ in the control group. Conclusion - Patients with dyspepsia who underwent routine duodenal biopsies did not show an increased risk for celiac disease when compared to healthy individuals.
\end{abstract}

HEADINGS - Celiac disease. Dyspepsia. Endoscopy.

\section{INTRODUCTION}

Celiac Disease $(\mathrm{CD})$ is an autoimmune disorder characterized by a chronic intestinal inflammatory response due to the ingestion of gluten, leading to some degree of villous atrophy and potential nutrient malabsorption ${ }^{(14)}$. Its diagnosis is based on the presence of histological signs of villous atrophy with increased intraepithelial lymphocites on duodenal biopsies and positive antibodies against specific targets, mainly tissue-transglutaminase, gliadin or endomysium ${ }^{(8)}$.

It has been widely accepted that typical clinical features include chronic diarrhea with malabsorption of nutrients ${ }^{(5)}$. However, it has become increasingly recognized that, especially among adults, "atypical" features are common clinical manifestations. As a consequence, iron-deficiency anemia even without gastrointestinal symptoms, or non-specific symptoms such as abdominal pain, vomiting or even Irritable Bowel Syndrome may be the main features of $\mathrm{CD}^{(17)}$.

In this context, dyspepsia has been regarded as a potential syndrome that may be associated with an increased risk of CD. Dyspepsia is a very common condition, that may be idiopathic or may be caused by a secondary condition, such as Helicobacter pylori chronic gastritis ${ }^{(15)}$.

Previous evidence trying to assess the risk of CD among dyspeptic patients has been inconclusive, showing in some cases notorious discrepancies ${ }^{(2,4,7,13)}$. This may be due to methodological differences in the way they were designed. Additionally, a relatively recent meta-analysis ${ }^{(9)}$ tried to assess the true nature of the aforementioned association by means of pooled analysis of these studies, showing a lack of association with no increased risk of CD in patients with dyspepsia.

Since meta-analysis conclusions may be heavily influenced by the quality of the studies that were included, more evidence on the subject may be necessary to confirm such findings. Furthermore, there is a relatively lack of experience in the context of a Latinamerican setting. As a consequence, we sought to determine the prevalence of $\mathrm{CD}$ in patients with dyspepsia compared to healthy controls without dyspepsia.

\section{METHODS}

A case-control study design was followed. This was a prospective study that evaluated patients with clinical suspicion of functional dyspepsia, according to Rome III criteria. The study protocol was evaluated and approved by our Institution's Ethics Committee. Every patient who agreed to participate signed an informed consent. The study was performed according to the Declaration of Helsinki's ethical principles.

\section{Study population}

From July 2012 to July 2015, patients over 18 years old under evaluation for dyspepsia at our Institution were invited to participate. After an interview and physical examination, these patients were offered an upper gastrointestinal endoscopy. Patients should not have any previous documentation of CD serology or Helicobacter pylori gastritis. These patients were regarded as cases.

Declared conflict of interest of all authors: none

Disclosure of funding: no funding received

* Gastroenterology Department. Instituto Quirúrgico del Callao. Buenos Aires, Argentina.

Correspondence: Juan Lasa. Libertad, 984 (1012). Buenos Aires, Argentina. E-mail: drjuanslasa@gmail.com 
On the other hand, asymptomatic adult volunteers who performed a preventive visit to their primary care physician were invited to participate and agreed to undertake an upper gastrointestinal endoscopy. These patients were recruited in a 1:1 fashion and were regarded as controls.

Functional Dyspepsia was defined according to Rome III criteria (Figure 1) ${ }^{(18)}$. Both cases and control patients were given the Rome III questionnaire on dyspepsia before endoscopy in order to confirm or rule out dyspepsia. Patients with anemia, diarrhea, unintentional weight loss or other gastrointestinal symptoms were excluded from the study.

\section{FUNCTIONAL DYSPEPSIA}

Symptoms for at least 3 months, with symptom onset at least at 6 months, associated with one or more of the following:

Early satiety

Epigastric Pain

Epigastric Burn

Upper abdominal fullness

FIGURE 1. Rome III criteria for Functional Dyspepsia

\section{Procedures}

Upper endoscopies were performed using High Definition Olympus endoscopes (Olympus ${ }^{\circledR}$ LatinAmerica, Miami, USA). A trained anesthesiologist performed sedation using endovenous propofol. Regardless of the endoscopic findings, in every patient four to six duodenal biopsies were taken (with at least one biopsy from the duodenal bulb). Those patients with histologic signs of villous atrophy (Marsh III according to Marsh-Obehuber classification (Figure 2$)^{(16)}$ were furtherly evaluated and serological tests were performed in order to determine the presence of anti-tissue transglutaminase (anti-tTG) and/or anti-endomysium antibodies ${ }^{(3)}$.

CD was defined as the presence of villous atrophy (Marsh III) associated with positive serological tests. CD prevalence was compared between both case and control groups.

\begin{tabular}{|ll|}
\hline \multicolumn{2}{|c|}{ MARSH - OBERHUBER CLASSIFICATION } \\
\hline MARSH I & Increased Intraepithelial Lymphocytes \\
\hline MARSH II & $\begin{array}{l}\text { Increased Intraepithelial Lymphocytes and Crypt } \\
\text { Hyperplasia }\end{array}$ \\
\hline MARSH IIIA & $\begin{array}{l}\text { Increased Intraepithelial Lymphocytes, Crypt } \\
\text { Hyperplasia and Partial Villous Atrophy }\end{array}$ \\
\hline MARSH IIIB & $\begin{array}{l}\text { Increased Intraepithelial Lymphocytes, Crypt } \\
\text { Hyperplasia and Subtotal Villous Atrophy }\end{array}$ \\
\hline MARSH IIIC & $\begin{array}{l}\text { Increased Intraepithelial Lymphocytes, Crypt } \\
\text { Hyperplasia and Total Villous Atrophy }\end{array}$ \\
\hline
\end{tabular}

FIGURE 2. Marsh Oberhuber classification

\section{Statistical analysis}

Stata $^{\circledR}$ software was used for this purpose (v11.1. Statacorp, College Station, Texas, USA). According to previous studies on the prevalence of $\mathrm{CD}$ in our population, we estimated a prevalence of $1.2 \%$ (results not published); we also estimated an expected CD prevalence among dyspeptic patients of 5\%. Considering a power of $80 \%$ and an alpha error of less than $5 \%$, at least 320 patients in each group should be recruited.

Categorical variables were described as percentages. Numerical variables were described as means with their standard deviations.
For the comparison of numerical variables, Student $t$ test was used. Conversely, chi square or Fisher's test was used for the comparison of categorical variables. Odds Ratios (OR) with their 95\% confidence intervals $(95 \% \mathrm{CI})$ were calculated. A p value of less than 0.05 was considered as statistically significant.

\section{RESULTS}

Overall, 320 patients with dyspepsia and 320 healthy controls were recruited. Demographic features of the recruited patients, such as gender and age, are shown in Table 1. No significant differences were found in terms of such features between groups.

TABLE 1. Demographic features of cases and controls

\begin{tabular}{lcccc}
\hline & $\begin{array}{c}\text { Patients with } \\
\text { Dyspepsia } \\
(\mathbf{n = 3 2 0 )}\end{array}$ & $\begin{array}{c}\text { Healthy } \\
\text { Controls } \\
(\mathbf{n = 3 2 0 )}\end{array}$ & OR (95\%CI) & $\begin{array}{c}\boldsymbol{P} \\
\text { Value }\end{array}$ \\
\hline $\begin{array}{l}\text { Gender } \\
\text { (Female) }\end{array}$ & $\begin{array}{c}65 \% \\
(208 / 320)\end{array}$ & $\begin{array}{c}68.41 \% \\
(219 / 320)\end{array}$ & $\begin{array}{c}0.85 \\
(0.61-1.19)\end{array}$ & 0.4 \\
Age & $50 \pm 12$ & $48 \pm 14$ & $\mathrm{~N} / \mathrm{A}$ & 0.6 \\
BMI & $24.5 \pm 4$ & $26.3 \pm 4.6$ & $\mathrm{~N} / \mathrm{A}$ & 0.08 \\
$\begin{array}{l}\text { Familiar history } \\
\text { of celiac disease }\end{array}$ & $\begin{array}{l}0.93 \% \\
(3 / 320)\end{array}$ & $\begin{array}{c}0.31 \% \\
(1 / 320)\end{array}$ & $\begin{array}{c}3.01 \\
(0.31-29.17)\end{array}$ & 0.6 \\
\hline
\end{tabular}

BMI: body mass index

Both endoscopic and histologic signs of villous atrophy were found in $1.25 \%(4 / 320)$ of patients in the dyspepsia group versus $0.62 \%(2 / 320)$ in the control group $(P=0.2)$ (Figure 3$)$. All the patients with villous atrophy were classified as Marsh IIIC and were female. Additionally, all the patients with villous atrophy showed positive IgA anti-tTG antibodies: in other words, there were no cases of seronegative celiac disease.

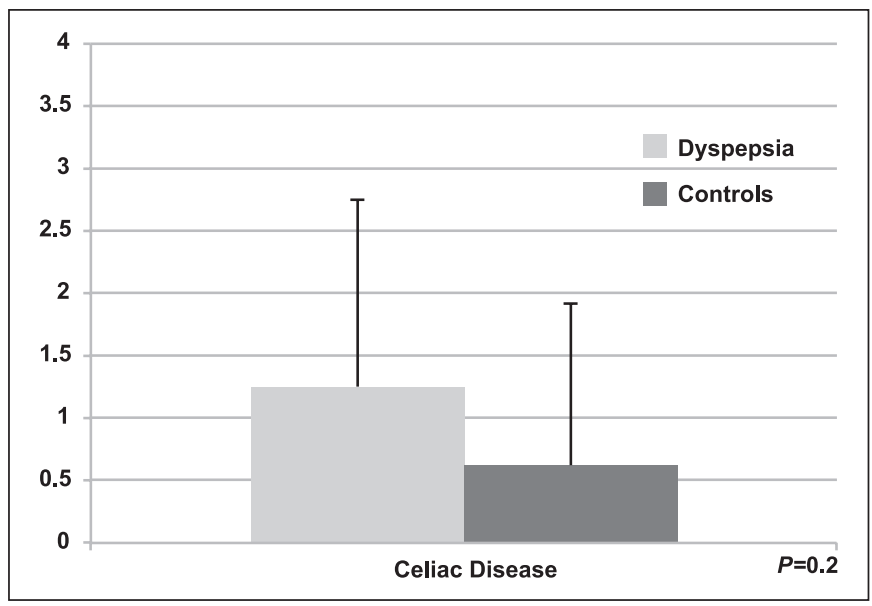

FIGURE 3. Prevalence of Celiac Disease between groups.

There was no significant difference (using Fisher extact test).

Table 2 shows the comparison of other endoscopic findings between groups. As it can be observed, there was a higher prevalence of erosive gastritis in the Dyspepsia group [32.81\% vs $17.81 \%$, OR 2.25 (1.55-19.04)]. All CD patients showing dyspeptic symptoms had complete resolution of their symptoms once they began gluten-free diet. 
TABLE 2. Comparison of endoscopic findings between groups

\begin{tabular}{lcccc}
\hline & $\begin{array}{c}\text { Patients with Dyspepsia } \\
(\mathrm{n}=320)\end{array}$ & $\begin{array}{c}\text { Healthy Controls } \\
(\mathrm{n}=320)\end{array}$ & OR (95\%CI) \\
\hline Erosive gastritis & $32.81 \%(105 / 320)$ & $17.81 \%(57 / 320)$ & $2.25(1.55-19.04)$ & 0.001 \\
Gastric ulcers & $5 \%(16 / 320)$ & $2.81 \%(9 / 320)$ & $1.81(0.79-4.17)$ \\
Erosive esophagitis & $10.31 \%(33 / 320)$ & $6.25 \%(20 / 320)$ & $1.72(0.96-3.07)$ & 0.2 \\
\hline
\end{tabular}

\section{DISCUSSION}

According to our results, the hypothesis of the study was not confirmed in the data analysis.

Over the last decades, atypical symptoms related to $\mathrm{CD}$ became an increasingly more frequent finding, especially in the adult population. As a consequence, $\mathrm{CD}$ can sometimes present with vague symptoms, such as nausea, vomiting or abdominal pain ${ }^{(6)}$. This should raise the awareness of physicians who evaluate such patients. Nevertheless, a systematic screening for CD is not recommended in this scenario. The same question arised in Irritable Bowel Syndrome (IBS) patients, with evidence showing conflicting results ${ }^{(17)}$.

Dyspepsia is common in the general population, with an estimated prevalence between $20 \%$ and $40 \%$ in population-based studies $^{(18)}$. Its prevalence is higher when patients who attend to Gastroenterology clinics are studied. Dyspepsia can be caused by a myriad of conditions. However, in many cases, upper endoscopy examination shows no significant abnormalities that may explain the symptoms ${ }^{(19)}$. Thus, a non-neglectable proportion of these patients are classified as having Functional Dyspepsia. It is noteworthy that many of these Functional Dyspepsia patients are not routinely tested to rule out $\mathrm{CD}^{(18)}$.

The question whether dyspeptic patients have an increased risk of $\mathrm{CD}$ has been previously assessed, with conflicting results ${ }^{(2,4,7,13)}$. Some limitations must be mentioned: some of these studies were underpowered or did not use a pre-specified definition of dyspepsia. Additionally, the definition of CD is highly variable among these studies, since some of them only rely on serologic tests for the diagnosis of CD instead of a biopsy-based diagnosis. This observation is reflected in a meta-analysis published by Ford et al. ${ }^{(9)}$. Although the results of the pooled analysis showed that there was not an increased risk of $\mathrm{CD}$ among patients with dyspepsia, heterogeneity in the quality of included studies is later mentioned by the authors. It is also worth noticing another relevant observation pointed out by the authors of the above-mentioned meta-analysis: there are few studies from Latin American countries. This contrasts with the vast experience that is published on the subject, especially in countries such as Brazil ${ }^{(11)}$ or Argentina ${ }^{(10)}$. Even though dyspepsia prevalence is much higher than the expected prevalence of $C D$ in the general population, CD prevalence in Latin American countries has been shown to be comparable to the prevalence from North American or European countries ${ }^{(1)}$. As a consequence, our experience in this matter may be paralleled to the experiences in other regions of the World.

Potential strenghts of this study may be, firstly, the a priori estimation of the sample size. Secondly, the selection of the control group, since these were completely healthy volunteers. Last but not least, it should be mentioned that the definition of CD was the most accurate as possible, so that a true estimation of its prevalence can be done. One potential limitation is that we did not assessed the genetical background of the patients by means of HLA DQ2/DQ8 analysis. This could have been an interesting piece of information in order to achieve a better description of the study population. As a matter of fact, a more profound genetic investigation in the CD population of Latin American patients should be carried out, since relevant features could be found out. Such is the case of the study undertaken by Kotze et al. ${ }^{(12)}$, where it is shown that a non-neglectable proportion of CD patients were both HLA-DQ2 and DQ8 negative.

In conclusion, patients with dyspepsia who underwent routine duodenal biopsies did not show an increased risk for CD when compared to healthy individuals. According to these results, a systematic CD screening in the population with dyspepsia cannot be recommended.

\section{Authors' contributions}

Lasa J: study design, statistical analysis, manuscript review. Spallone L: data collection, manuscript writing. Gandara S: data collection, manuscript writing. Chaar E: data collection, manuscript writing. Berman S: study design, bibliographic review. Zagalsky D: study design, critical review of manuscript draft.

Lasa J, Spallone L, Gandara S, Chaar E, Berman S, Zagalsky D. A prevalência de doença celíaca não é aumentada em pacientes com dispepsia funcional. Arq Gastroenterol. 2017,54(1):37-40.

RESUMO - Contexto - As evidências ao avaliar o risco da doença celíaca entre pacientes dispéptico têm sido inconclusivas, mostrando discrepâncias notórias em alguns casos. Objetivo - Determinar a prevalência da doença celíaca em pacientes com dispepsia em comparação com controles saudáveis sem dispepsia. Métodos - Pacientes adultos sob avaliação para dispepsia foram convidados a participar. A estes pacientes foi oferecida uma endoscopia digestiva com biópsias duodenais. Por outro lado, voluntários adultos assintomáticos, que realizaram uma visita preventiva ao seu médico de atenção primária foram convidados a participar e concordaram em realizar endoscopia digestiva com biópsias duodenais também. Naqueles pacientes com sinais histológicos de atrofia das vilosidades foram melhor avaliados e foram realizados testes sorológicos para determinar o diagnóstico de doença celíaca. A prevalência de doença celíaca foi comparada entre os grupos. Resultados - No total, 320 pacientes com dispepsia e 320 controles saudáveis foram recrutados. Não houve nenhuma diferença significativa entre os grupos em termos de sexo ou idade. O diagnóstico de doença celíaca foi feito em $1,25 \%$ (4/320) dos pacientes no grupo de dispepsia, contra $0,62 \%$ (2/320) no grupo controle. Conclusão - Pacientes com dispepsia submetidos a biópsias duodenais de rotina não têm risco aumentado para a doença celíaca quando comparados com indivíduos saudáveis.

DESCRITORES - Doença celíaca. Dispepsia. Endoscopia. 


\section{REFERENCES}

1. Alencar ML, Ortiz-Agostinho CL, Nishitokukado L, et al. Prevalence of celiac disease among blood donorsin Sao Paulo: the most populated city in Brazil. Clinics (Sao Paulo). 2012;67:1013-8

2. Altintas E, Senli MS, Sezgin O. Prevalence of celiac disease among dyspeptic patients: A community-based case-control study. Turk J Gastroenterol. 2008;19:81-4

3. Bardella MT, Minoli G, Radaelli F, et al. Reevaluation of duodenal endoscopic markers in the diagnosis of celiac disease. Gastrointest Endosc. 2000;51:714-6.

4. Bardella MT, Minoli G, Ravizza D, et al. Increased prevalence of celiac disease in patients with dyspepsia. Arch Intern Med. 2000;160:1489-91.

5. Bhattacharya M, Kapoor S, Dubey AP. Celiac disease presentation in a tertiary referral centre in India: current scenario. Indian J Gastroenterol. 2013;32:98-102.

6. Bottaro G, Cataldo F, Rotolo N, et al. The clinical pattern of subclinical/silen celiac disease: an analysis on 1026 consecutive cases. Am J Gastroenterol. 1999;94:691-6.

7. de Lima VM, Gandolfi L, Pires JAA, Pratesi R. Prevalence of celiac disease in dyspeptic patients. Arq Gastroenterol. 2005;42:153-6.

8. Fasano A, Catassi C. Clinical practice. Celiac disease. N Engl J Med. 2012 20;367:2419-26.

9. Ford A, Ching E, Moayyedi P. Meta-analysis: yield of diagnostic tests for coeliac disease in dyspepsia. Aliment Pharmacol Ther. 2009;30:28-36.

10. Gomez JC, Selvaggio Gs, Viola M et al. Prevalence of celiac disease in Argentina: screening of an adult population in the La Plata area. Am J Gastroenterol. 2001;96:2700-4.
11. Kotze LM. Celiac disease in Brazilian patients: associations, complications and causes of death. Forty years of clinical experience. Arq Gastroenterol. 2009;46:261-9.

12. Kotze LM, Nisihara R, Ramos da Rosa Utiyama S, Kotze LR. Absence of HLA DQ2 and HLA-DQ8 does not exclude celiac disease in Brazilian patients. Rey Esp Enf Dig. 2014;106:561-2.

13. Locke GR III, Murray JA, Zinsmeister AR, et al. Celiac disease serology in irritable bowel syndrome and dyspepsia: A population-based case-control study. Mayo Clin Proc. 2004;79:476-82.

14. Ludvigsson JF, Leffler DA, Bai JC, et al. The Oslo definitions for coeliac disease and related terms. Gut. 2013;62:43-52.

15. Mearin F. Qué es la dispepsia, la dispepsia orgánica y la dispepsia funcional? Acta Gastroenterol Latinoam. 2007;37:178-82.

16. Oberhuber G. Histopathology of celiac disease. Biomed Pharmacother 2000;54:368-72.

17. Shayesteh AA, Hajiani E, Hashemi SJ, et al. Prevalence of celiac disease in Iranian patients with irritable bowel syndrome: a cross-sectional study. J Dig Dis. 2014;15:12-7.

18. Talley N, Vakil N. Guidelines for the management of Dyspepsia. Am J Gastroenterol. 2005;100:2324-37.

19. Yang YX, Brill J, Krishnan P, et al. American Gastroenterological Association Institute Guideline on the role of upper gastrointestinal biopsy to evaluate dyspepsia in the adult patient in the absence of visible mucsoal lesion. Gastroenterology. 2015;149:1082-7. 